Article

\title{
Species-Specific Inactivation of Triosephosphate Isomerase from Trypanosoma brucei: Kinetic and Molecular Dynamics Studies
}

\author{
Alejandra Vázquez-Raygoza ${ }^{1}$, Lucia Cano-González ${ }^{2}$, Israel Velázquez-Martínez ${ }^{2}$, \\ Pedro Josué Trejo-Soto ${ }^{2}$, Rafael Castillo ${ }^{2}$, Alicia Hernández-Campos ${ }^{2}$, \\ Francisco Hernández-Luis ${ }^{2}$, Jesús Oria-Hernández ${ }^{3}$ (D), Adriana Castillo-Villanueva ${ }^{3}$, \\ Claudia Avitia-Domínguez ${ }^{1}$, Erick Sierra-Campos ${ }^{4}$, Mónica Valdez-Solana ${ }^{4}$ and \\ Alfredo Téllez-Valencia ${ }^{1, *}$ \\ 1 Faculty of Medicine and Nutrition, Juarez University of Durango State, Av. Universidad y Fanny Anitua \\ S/N, Durango 34000, Mexico; avazquezraygoza@gmail.com (A.V.-R.); avitiaclaudia@gmail.com (C.A.-D.) \\ 2 School of Chemistry, Pharmacy Department, National Autonomous University of Mexico, \\ Mexico City 04510, Mexico; qfblucia@gmail.com (L.C.-G.); Ivelazquez00@hotmail.com (I.V.-M.); \\ Piter_jo@comunidad.unam.mx (P.J.T.-S.); rafaelc@unam.mx (R.C.); hercam@unam.mx (A.H.-C.); \\ franher@unam.mx (F.H.-L.) \\ 3 Biochemistry and Genetics Laboratory, National Institute of Pediatrics, Ministry of Health, \\ Mexico City 04534, Mexico; jesus.oria.inp@gmail.com (J.O.-H.); acastilloinp@gmail.com (A.C.-V.) \\ 4 Faculty of Chemical Sciences, Juarez University of Durango State, Av. Artículo 123 S/N Fracc. Filadelfia, \\ Gomez Palacio, Durango 35010, Mexico; ericksier@gmail.com (E.S.-C.); valdezandyval@gmail.com (M.V.-S) \\ * Correspondence: atellez@ujed.mx; Tel./Fax: +52-618-812-1687
}

Received: 7 November 2017; Accepted: 21 November 2017; Published: 24 November 2017

\begin{abstract}
Human African Trypanosomiasis (HAT), a disease that provokes 2184 new cases a year in Sub-Saharan Africa, is caused by Trypanosoma brucei. Current treatments are limited, highly toxic, and parasite strains resistant to them are emerging. Therefore, there is an urgency to find new drugs against HAT. In this context, T. brucei depends on glycolysis as the unique source for ATP supply; therefore, the enzyme triosephosphate isomerase (TIM) is an attractive target for drug design. In the present work, three new benzimidazole derivatives were found as TbTIM inactivators (compounds 1, 2 and 3) with an $\mathrm{I}_{50}$ value of 84,82 and $73 \mu \mathrm{M}$, respectively. Kinetic analyses indicated that the three molecules were selective when tested against human TIM (HsTIM) activity. Additionally, to study their binding mode in TbTIM, we performed a $100 \mathrm{~ns}$ molecular dynamics simulation of TbTIM-inactivator complexes. Simulations showed that the binding of compounds disturbs the structure of the protein, affecting the conformations of important domains such as loop 6 and loop 8 . In addition, the physicochemical and drug-like parameters showed by the three compounds suggest a good oral absorption. In conclusion, these molecules will serve as a guide to design more potent inactivators that could be used to obtain new drugs against HAT.
\end{abstract}

Keywords: human African trypanosomiasis; triosephosphate isomerase; enzymatic kinetics; molecular dynamics simulation

\section{Introduction}

Human African Trypanosomiasis (HAT), also known as sleeping sickness, is part of the tropical neglected diseases group. It is a painful and prolonged suffering ailment, in which people often die if they do not get the appropriate treatment. The World Health Organization reported 2184 new cases, with approximately 70 million people at risk in 2016 [1]. Actually, only four drugs are used in the sleeping sickness treatment, melarsoprol, pentamidine, suramin, and, recently, the combined 
therapy of eflornitine/nifurtimox (NECT) [2]. The treatment is ineffective because it has limitations ranging from poor efficacy, acute toxicity, and parasite resistance [3-7]. Therefore, there is an urgency to develop new drugs against HAT.

HAT is a parasitic disease caused by the protozoan Trypanosoma brucei, which is transmitted by the bite of flies from the Glossina genus [8]. The parasite proliferates extracellularly in the mammalian bloodstream, and it has been demonstrated that the glycolysis is essential for survival as the only source for ATP supply [9]. Thus, the glycolytic enzymes are attractive targets mainly for their principal role in the energy production in parasites. In this context, the glycolytic enzyme triosephosphate isomerase (TIM) has been proposed by different research groups as a validated target for drug design against $T$. brucei [10-12].

Triosephosphate isomerase (E.C. 5.3.1.1) catalyzes the interconversion between glyceraldehyde-3phosphate and dihydroxyacetone phosphate in the fifth step of the glycolytic pathway [13]. Structurally, TIM from T. brucei (TbTIM) is a homodimeric enzyme, and each monomer consists of 250 residues forming eight parallel $\beta$-strands surrounded by eight $\alpha$-helices, showing the classical TIM barrel folding [10]. The active site is formed by Lys13, His95, and Glu167, the key residues for catalysis [14]; however, Asn11 has been reported as an important residue [15]. The interface between monomers occupies a significant portion of the molecular surface area of each monomer, approximately $1530 \AA^{2}$ for TbTIM [16]. Similar to other isoforms, TbTIM is active only in its dimeric form, and several reports have shown that the use of small molecules to target the dimer interface induce structural modifications leading to enzyme inactivation [11,17-19]. With respect to TbTIM, there are only two reports about enzyme inactivation [11,17], the other two referring to enzyme inhibition [20,21].

On the other hand, in the search for new drugs, one of the important privileged scaffolds is the benzimidazole nucleus [22] because it has shown different biological activities such as cell antiproliferative effects [23], antioxidant properties [24], antiviral [25], antimicrobial [26], antitumor [27], anti-HIV [28], antiparasitic [29], anti-obesity and anti-diabetic [30].

In this context, benzimidazole derivatives synthetized by our group have shown biological activity against several parasites [31-35], and some of them have shown inactivation of Trypanosoma cruzi TIM (TcTIM) [36-38]. In the present work, we searched TbTIM inactivators from our in house library of benzimidazole derivatives. Three compounds were able to inactivate selectively the $\mathrm{TbTIM}$, and their inactivation mechanism was characterized through enzyme kinetics and molecular dynamics simulations.

\section{Results and Discussion}

\subsection{TbTIM Inactivation}

In order to find hits for the development of new drugs against HAT, our in house library of 200 benzimidazole derivatives was tested against TbTIM, as described in the Materials and Methods section. From 200 molecules assessed, only three were able to inactivate TbTIM more than 50\%, twenty-four less than $50 \%$ and up to $20 \%$, and the rest under $20 \%$. According to these data, the three most potent were selected for kinetic and structural characterization studies (compounds 1, 2, and 3, Figure 1).

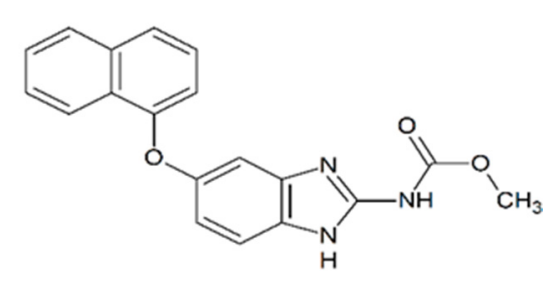

1

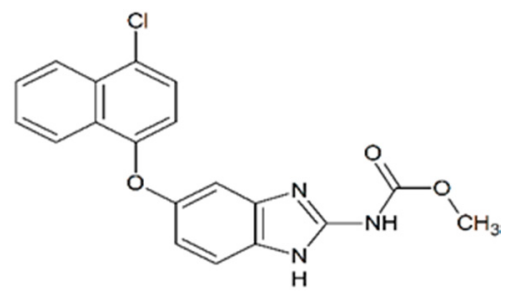

2

Figure 1. Cont. 
<smiles>CSc1nc2cc(C(=O)N/N=C/c3ccc([N+](=O)[O-])o3)ccc2[nH]1</smiles>

3

Figure 1. Structure of TbTIM inactivators.

Kinetic studies showed that compounds inactivated the enzyme in a concentration-dependent manner obtaining $\mathrm{I}_{50}$ values of 84,82 , and $73 \mu \mathrm{M}$ for compounds 1, 2 and 3, respectively (Figure 2). Something interesting to highlight is that the inactivation curves of compounds $\mathbf{1}$ and $\mathbf{2}$ showed a sigmoidal decay behavior (Figure 2a,b), although the curves did not reach $100 \%$ of inactivation. This is supported by the $n$ value close to two obtained in both cases. This suggests that the enzyme inactivation is a cooperative process, which involves at least two molecules of each compound [17], whilst compound 3 showed a hyperbolic behavior with an $n$ value close to 1 , suggesting that only one molecule was necessary for enzyme inactivation (Figure 2c). This behavior was similar to TcTIM inactivators reported previously $[11,17,19]$. Additionally, inactivation of TbTIM was reported in the same concentration range to that found here.

To continue with characterization, the pseudo-first-order rate constant $\left(\mathrm{k}_{\mathrm{obs}}\right)$ was obtained and plotted against the respective compound concentration to calculate the apparent second-order-rate constant $\left(\mathrm{k}_{2 \text { app }}\right.$ ) (Figure $\left.2 \mathrm{~d}-\mathrm{f}\right)$. Moreover, due to solubility problems, a complete curve could not be generated; therefore, it was not possible to determine the value of $k_{2 a p p}$. Nevertheless, an interesting observation from the curves is that, in all cases, there was a tendency to saturation. This suggests that the inactivation velocity was dominated by the equilibrium between the association and dissociation of enzyme-compound complex [39], which means that, at high compound concentrations, the rate of inactivation will not change. This pattern was observed for TcTIM inactivators even using different types of molecules such as benzothiazole derivatives [17] or natural products [19].
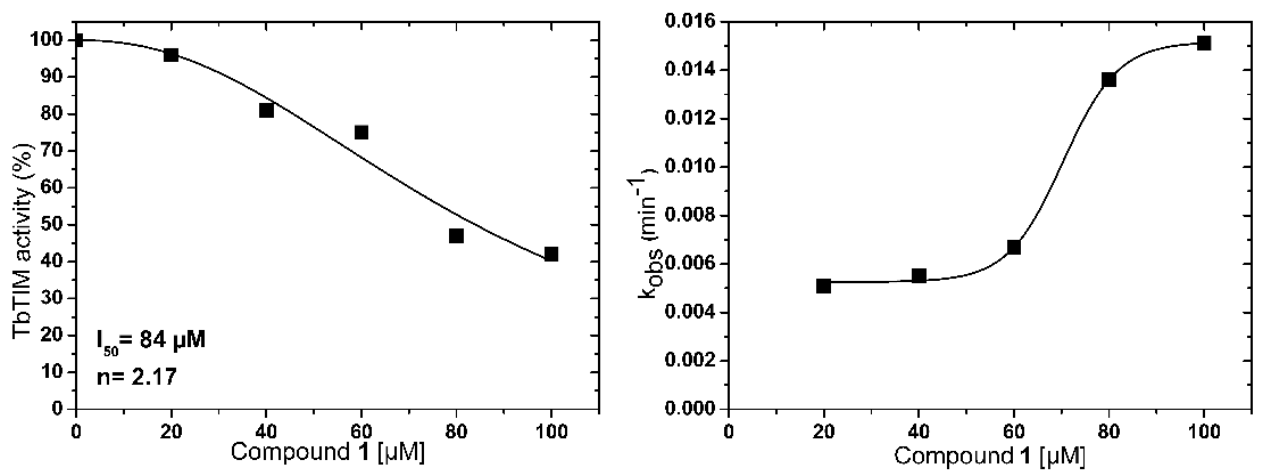

(a)
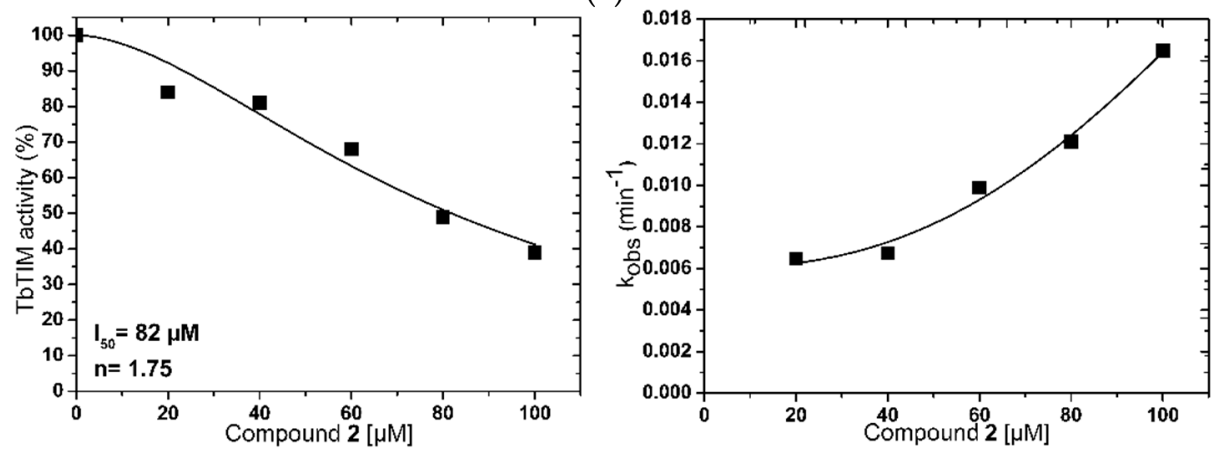

(b)

Figure 2. Cont. 

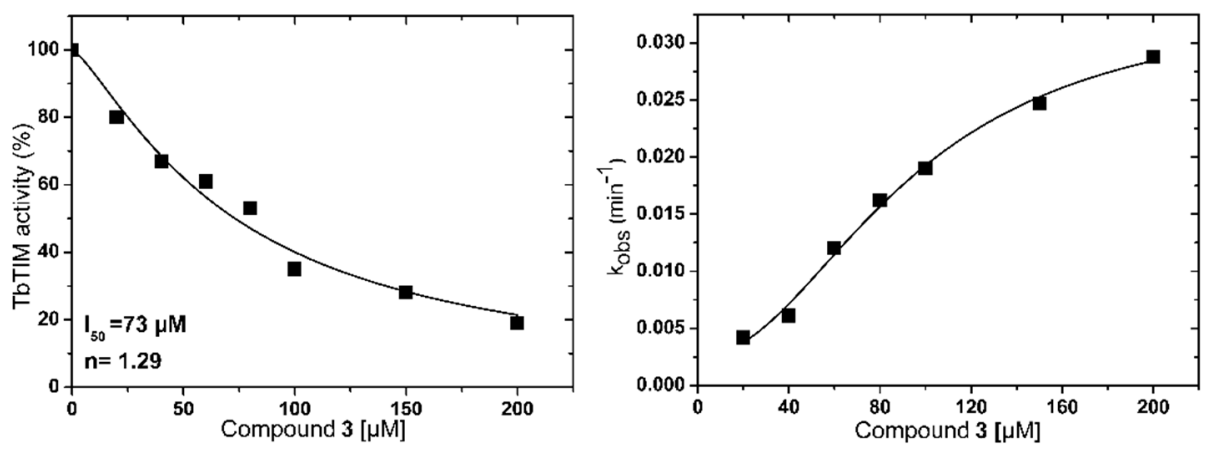

(c)

Figure 2. Activity of TbTIM (left panel) and plots of the pseudo-first-order rate constants (right panel) at different concentrations of compounds (a) 1 ; (b) 2 and (c) 3 . I 50 value was defined as the concentration of compound needed to reduce the enzymatic activity to $50 \%$ and determined through curves at different compound concentrations and a Hill coefficient, $n$, is a measure of the degree of cooperativity of the ligands.

In order to continue kinetic characterization and take into account that TbTIM is active only in its dimeric form, it was considered important to determine if compounds act interfering in the association and dissociation process between monomers, which means if compounds bind into the dimer interface. To this end, assays at different enzyme concentrations and a fixed compound concentration were carried out. The results showed that, in the three cases, when the enzyme concentration increases, the effect of compound diminishes, suggesting that compounds 1, 2, and 3 are binding at the dimer interface of TbTIM (Figure 3). In the same way, this behavior was observed in TcTIM inactivators $[17,19,21,40]$.

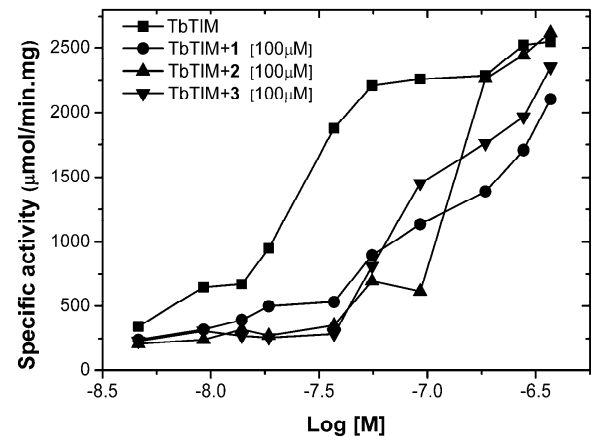

Figure 3. Effect of compounds 1, 2 and 3 at different concentrations of TbTIM.

\subsection{Molecular Dynamics}

After kinetics studies, molecular dynamics simulations of 100 ns were performed to characterize the interaction between TbTIM and compounds 1, 2, and 3. In the case of $\mathbf{1}$ and $\mathbf{2}$ and in accordance with that observed in kinetic data, two molecules of each compound were docked into the TbTIM interface, whilst, for compound 3, only one was used. Firstly, the system stability was evaluated by means of RMSD (root mean square deviation) value. For each MD simulation, the first 10 ns were discarded as the equilibration period from further analysis. Then, the RMSD showed that the four systems, free enzyme (Apo-TbTIM), TbTIM-1, TbTIM-2, and TbTIM-3, obtained an RMSD of $0.3 \mathrm{~nm}$ among $\mathrm{C} \alpha$ from initial to final structure conformation, supporting that the system was stable during the simulation time (Figure 4). Moreover, a fact worth highlighting is the significantly different behaviors observed in the RMSD trajectory in each TbTIM-compound complex, being the most remote to the Apo the TbTIM-2 complex. This indicates that the three systems underwent conformational changes to some degree, a behavior observed in other TIM-ligand complexes such as TcTIM-1,2,6-thiadiazine derivatives [41] and TcTIM-benzothiazole derivative [42]. 


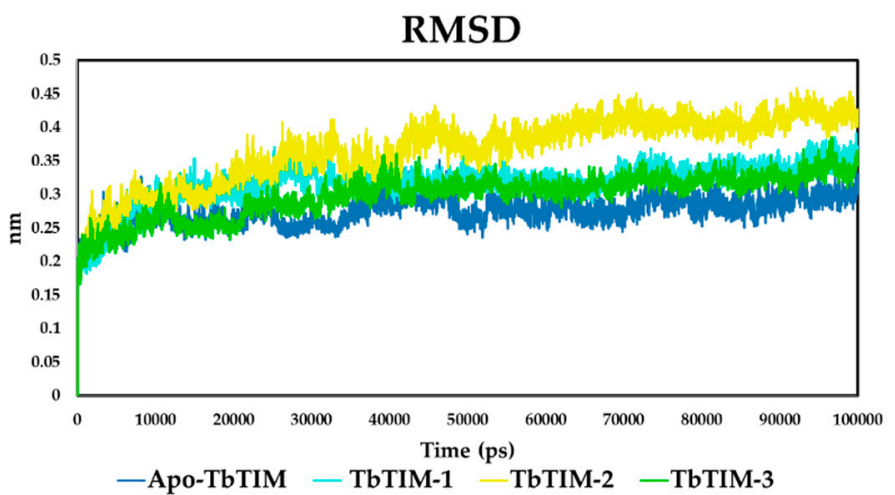

Figure 4. Root mean square deviation (RMSD) of free enzyme (Apo-TbTIM) and the TbTIMcompound complexes.

Thereafter, to determine flexible regions in TbTIM structure, the Residue Mean-Square Fluctuations (RMSF) between Apo-TbTIM and each TbTIM-compound complex was carried out (Figure 5). The RMSF graphic showed differences between the Apo-TbTIM and complexes, a two-way ANOVA analysis with the null hypothesis that the ligand binding has no effect on the RMSF, yielded $p$-values of $0.013,0.011$, and $0.001(<0.05)$ for compounds $\mathbf{1}, \mathbf{2}$, and $\mathbf{3}$, respectively. This data rejects the null hypothesis and supports that the differences observed were because of ligand binding (Figure 5a). Moreover, based on backbone structure superposition, some clear differences were observed between the three complexes and Apo-TbTIM (Figure 5b-d).
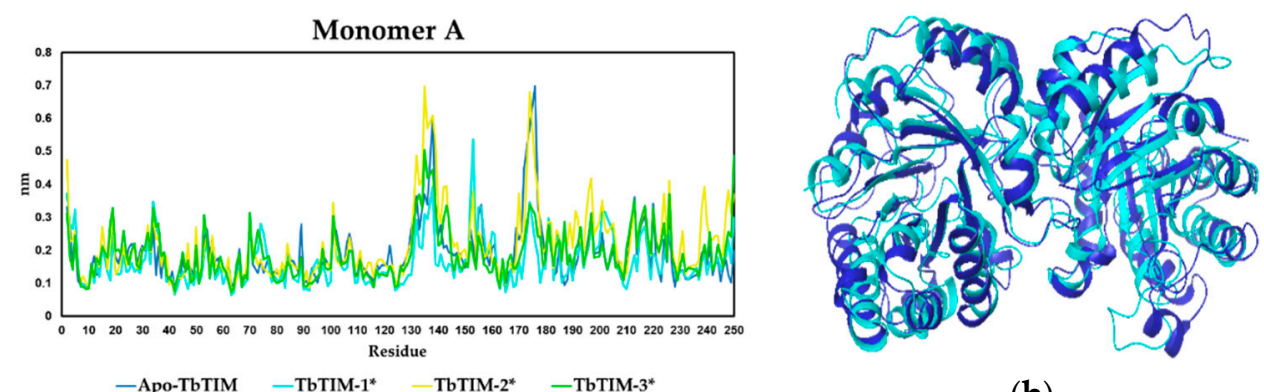

(b)

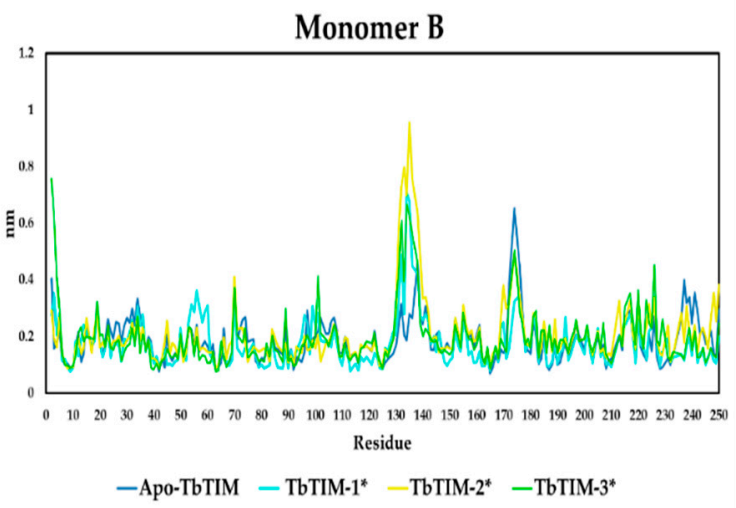

(a)

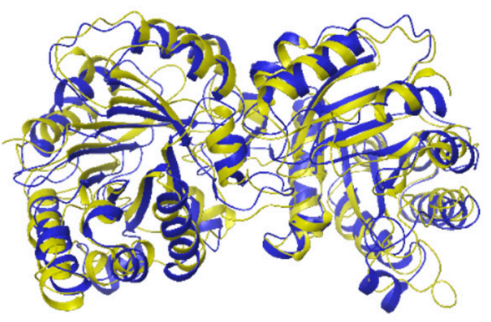

(c)

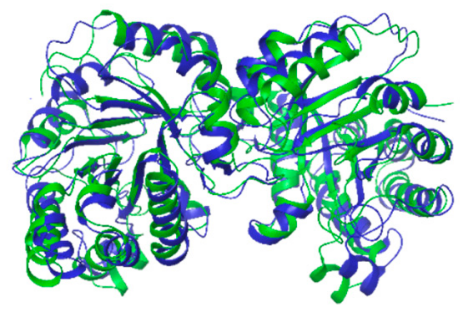

(d)

Figure 5. (a) Residue Mean-Square Fluctuations from monomer A and B ( $\left.{ }^{*} p<0.05\right)$. Superimposed average structures of Apo-TbTIM (blue) with TbTIM-1 (b); TbTIM-2 (c); and TbTIM-3 (d). The alignments were made based on backbone. 


\subsubsection{Structural Analyses of the TbTIM-Ligand Complex}

In order to describe in detail the different conformations obtained along the $100 \mathrm{~ns}$ simulation, a clustering analysis based on size was performed with respect to RMSD. This takes into account the cluster with more structures in the same conformation and the main cluster of each group was selected for the binding ligand analysis.

As it was stated before, two molecules of compounds $\mathbf{1}$ and $\mathbf{2}$ were docked on the TbTIM interface (Figure S1a,b). For compound 1, one molecule formed hydrogen bonding with Gly103 and Thr105 from monomer A, whilst the other molecule showed hydrogen bonding with Gln132 and Ala100 from monomer B (Figure 6a). In the case of compound 2, for both molecules docked, no hydrogen bonds (H-bond) were established with any of monomers (Figure $6 \mathrm{~b}$ ). In fact, during $65 \%$ of MD simulation, no hydrogen bonds were detected; however, the two molecules were stable during the simulation. In relation to compound 3 (Figure S1c), the molecule showed a hydrogen bond with Lys70 from monomer A (Figure 6c) with a prevalence of $40 \%$ through MD. These data agreed with the average of $\mathrm{H}$-bond found in MD analysis (Table 1). Similar binding modes have been observed for TcTIM inactivators [19,42-45]. The results emphasize the importance of the hydrophobic tunnel, which is formed at the dimer interface, where different types of ligands can be bound for the enzyme inactivation [11].

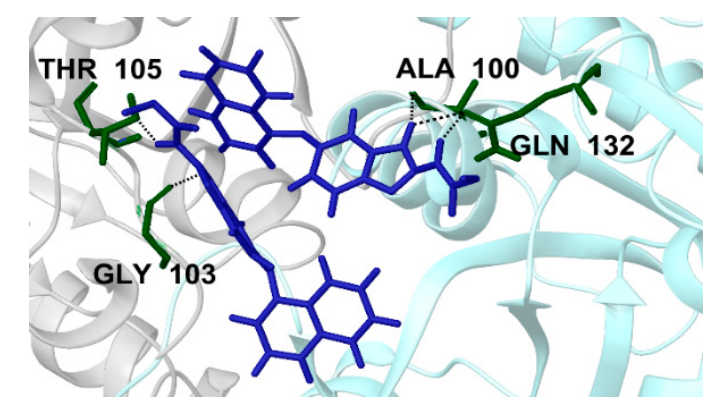

(a)

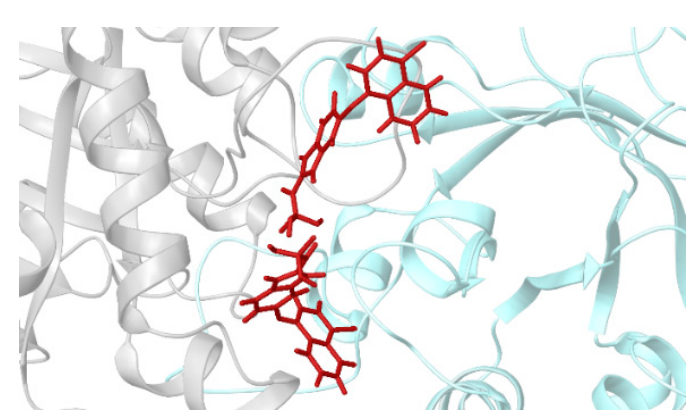

(b)

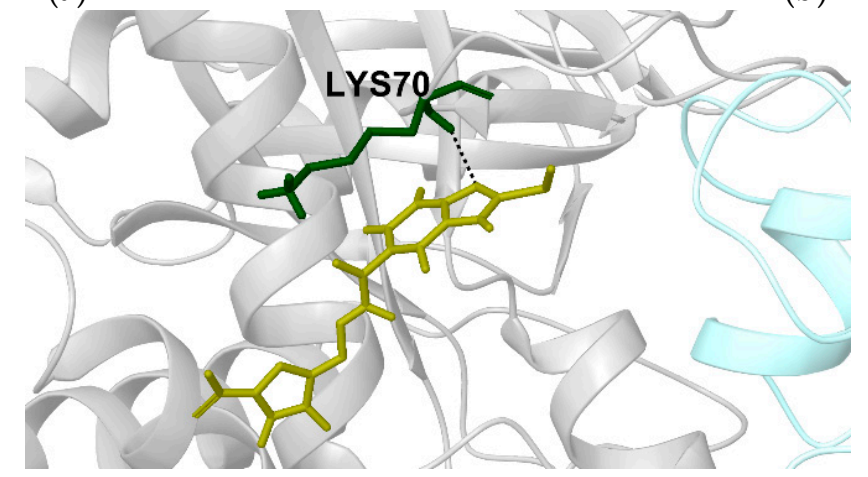

(c)

Figure 6. Binding mode of compounds 1, 2 and 3 on TbTIM (Light Gray ribbons monomer A and Light turquoise ribbons monomer B. (a) two molecules of compound $\mathbf{1}$ (blue sticks); (b) two molecules of compound 2 (red sticks); and (c) compound 3 (yellow sticks). H-bonds are depicted as dotted lines.

Additionally, Linear Interaction Energy (LIE) analysis revealed that the binding energy of compounds $\mathbf{1}$ and $\mathbf{2}$ was dominated by the van der Waals component, whilst, in compound $\mathbf{3}$, it was dominated by the electrostatic interaction energy (Table 1). It is worth highlighting that, in order to obtain the $\left(\mathrm{V}_{\mathrm{CL}}\right)_{\text {free }}$ and $\left(\mathrm{V}_{\mathrm{LJ}}\right)_{\text {free }}$ values in compounds $\mathbf{1}$ and $\mathbf{2}$, the average of the energy between the two molecules bounded was calculated. 
Table 1. Binding free energies calculated by the Linear Interaction Energy method and hydrogen bonds of the complexes during molecular dynamics.

\begin{tabular}{cccccccc}
\hline Complex & \multicolumn{4}{c}{ Energy $(\mathbf{k c a l} / \mathbf{m o l})$} & \multicolumn{2}{c}{ Hydrogen Bond } \\
\hline & $\left(\mathbf{V}_{\mathbf{L J}}\right)_{\text {bound }}$ & $\left(\mathbf{V}_{\mathbf{L J}}\right)_{\text {free }}$ & $\left(\mathbf{V}_{\mathbf{C L}}\right)_{\text {bound }}$ & $\left(\mathbf{V}_{\mathbf{C L}}\right)_{\text {free }}$ & $\Delta \mathbf{G}_{\text {bind }}$ & Range & Average \\
\hline TbTIM-1 & -29.45 & -6.53 & -4.45 & -1.28 & -5.71 & $0-7$ & 2 \\
TbTIM-2 & -38.90 & -2.67 & -0.92 & -0.33 & -6.82 & $0-6$ & 0 \\
TbTIM-3 & -27.52 & -8.49 & -44.83 & -43.59 & -4.05 & $1-7$ & 1 \\
\hline
\end{tabular}

$(\mathrm{VLJ})_{\text {bound }}$ average Lennard-Jones energy for ligand-protein interaction; (VLJ) free $_{\text {is }}$ ise average Lennard-Jones energy for ligand-water interaction; (VCL)bound is the average electrostatic energy for ligand-protein interaction; $(\mathrm{VCL})_{\text {free }}$ is the average electrostatic energy for ligand-water interaction.

\subsubsection{TbTIM Loop 6 and Loop 8 Dynamics}

The TIM is a perfectly evolved enzyme formed by two monomers, each one with an independent catalytic site [14]. Moreover, neither cooperativity nor allosterism has been observed between the two active sites $[18,46]$. Nevertheless, the importance of certain domains such as loop 6 or catalytic loop (Glu168-Pro178) and loop 8 (Gly235-Lys240) has been reported [47-51]. For this reason, it was decided to carry out an analysis by clustering specifically in these regions along the MD simulations.

The importance of conformational dynamics and flexibility of loop 6 to carry out the catalysis has been reported, and it closes on the substrate and protects it from exposure to the solvent [52]. Specifically, the closed state of loop 6 during the enzyme-substrate complex formation is stabilized by the interaction between the phosphate-loop gripper phase and the phosphodianion of the substrate [53]. Here, a possible conformational change was observed between the Apo-TbTIM and the complexes, as was suggested by the differences in RMSF of the residues that are part of the loop (Figure S2a). The apparent formation of an $\alpha$-helix was detected in Apo-TbTIM enzyme and in TbTIM-1 complex, being more evident in the Apo-TbTIM form. In contrast, no possible secondary structure formation was presented in TbTIM-2 and TbTIM-3 complexes (Figure 7). Therefore, our data suggest that the perturbation in the dynamics of this domain observed with the inactivators could explain in part the enzyme inactivation.

On the other hand, loop 8 analysis showed that, in the three complexes, as well as in loop 6, there were possible conformational changes (Figure S2b), more evident with compounds $\mathbf{1}$ and 2, suggesting the formation of an $\alpha$-helix (Figure 8a-c). TbTIM-3 complex had more movement. This is because of side chain fluctuations, which led to the site instability (Figure $8 \mathrm{~d}$ ).

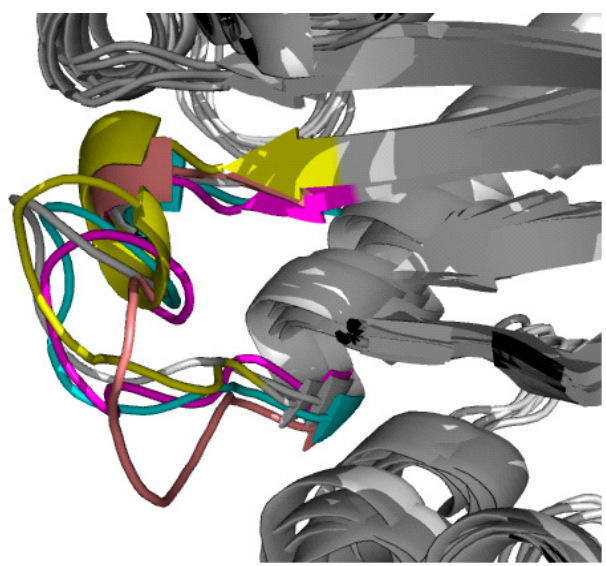

(a)

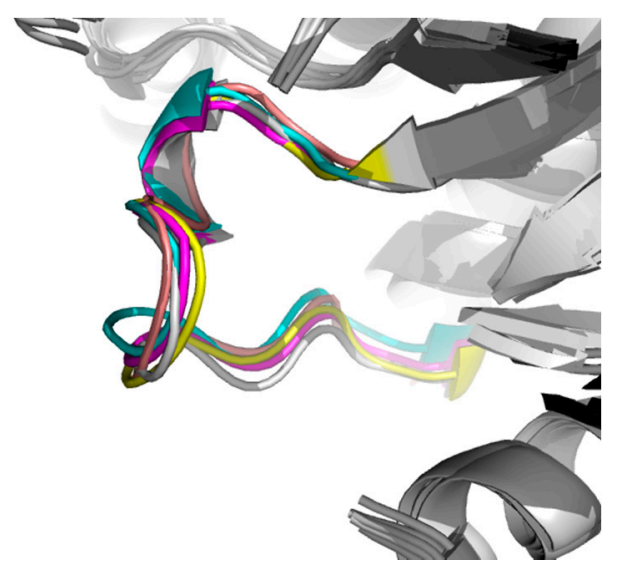

(b)

Figure 7. Cont. 


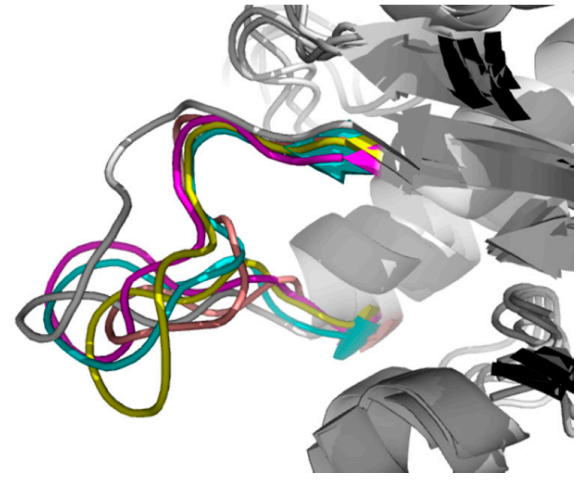

(c)

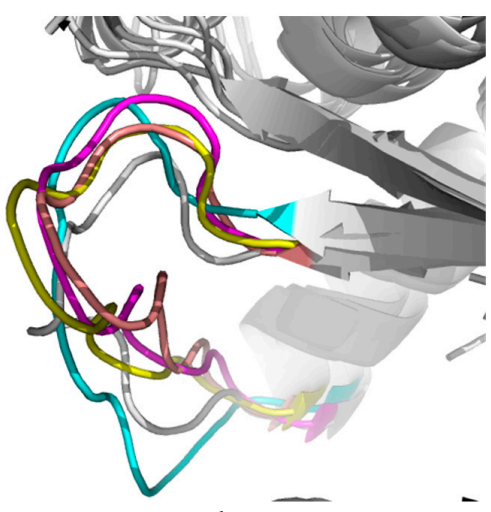

(d)

Figure 7. Catalytic loop 6 dynamics in (a) Apo-TbTIM; (b) TbTIM-1; (c) TbTIM-2; and (d) TbTIM-3. Cluster 1 (gray), Cluster 2 (cyan), Cluster 3 (magenta), Cluster 4 (yellow) and Cluster 5 (pink). The alignments were made based on backbone.

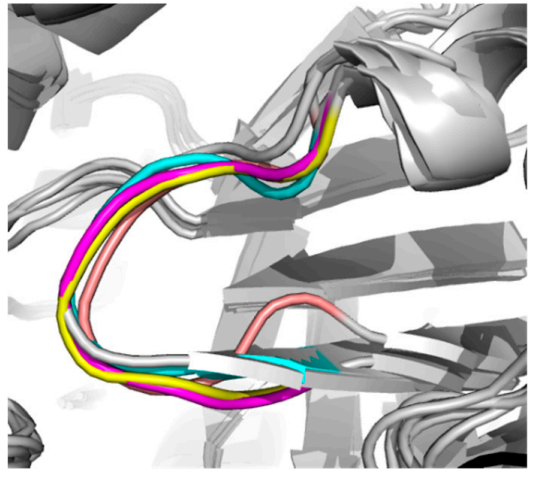

(a)

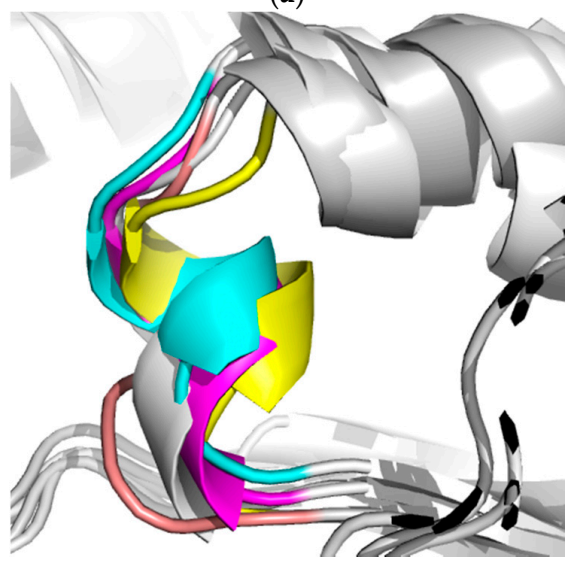

(c)

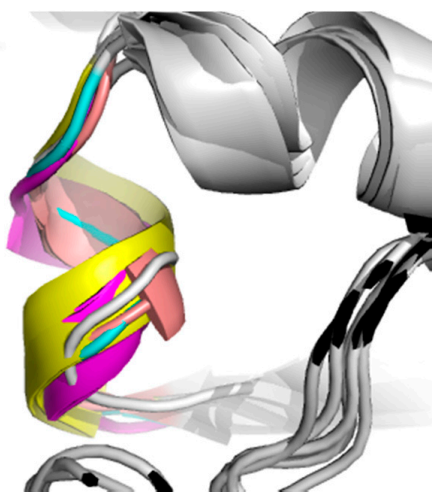

(b)

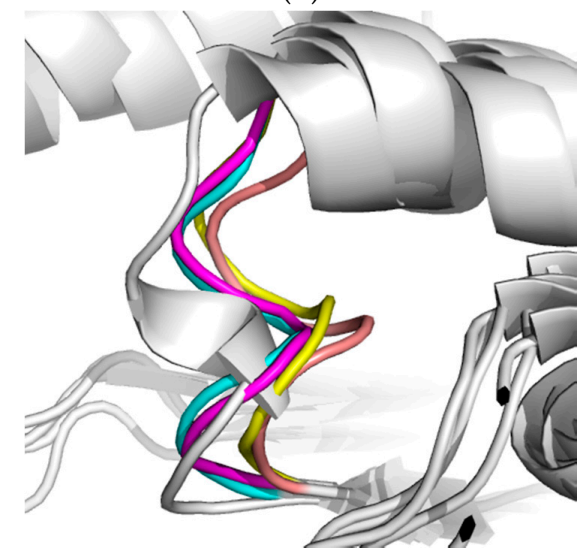

(d)

Figure 8. Loop 8 dynamics in (a) Apo-TbTIM; (b) TbTIM-1; (c) TbTIM-2; and (d) TbTIM-3. Cluster 1 (gray), Cluster 2 (cyan), Cluster 3 (magenta), Cluster 4 (yellow) and Cluster 5 (pink). The alignments were made based on backbone.

It has been described that loop 6, loop 7, and loop 8 contribute to the active site geometry through $\mathrm{H}$-bond interactions with the substrate [52]. Therefore, we decided to analyze and compare this region in the main cluster of the Apo-TbTIM with the three complexes. The results showed that there were differences in the geometry of the side chain in residues at the catalytic site (Figure 9a-c). Despite the compounds being bound at the dimer interface, and not interacting directly with catalytic residues, these changes indicated that the binding of compounds modify the global conformation of the protein, such that there was a change in the flexibility and conformational dynamics of the 
enzyme, suggesting that probably this conformational change entails the loss of the enzyme activity. Taking together all the data described above, it can be stated that the binding of compounds $\mathbf{1}, \mathbf{2}$ and 3 into the TbTIM interface affected the conformational dynamics of the enzyme, and these changes could be responsible for the loss of enzymatic activity observed in the in vitro assays.

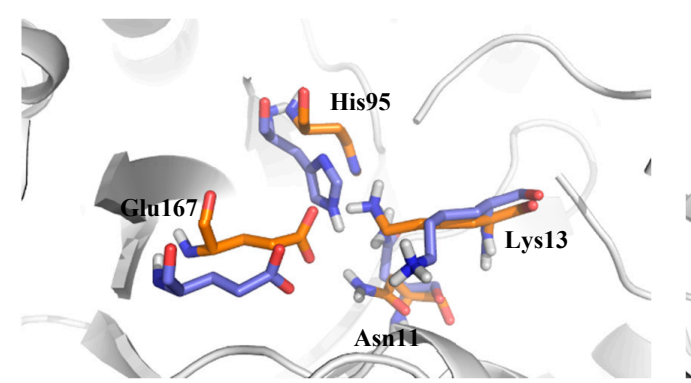

(a)

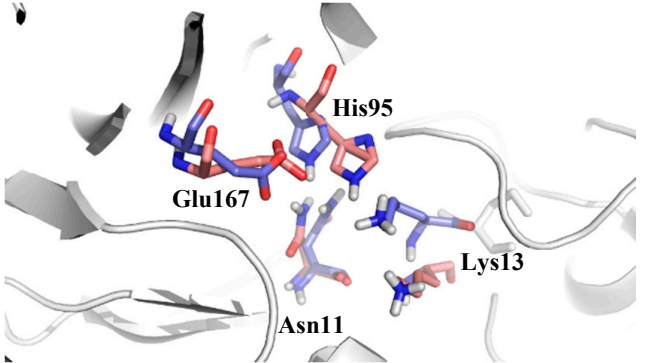

(b)

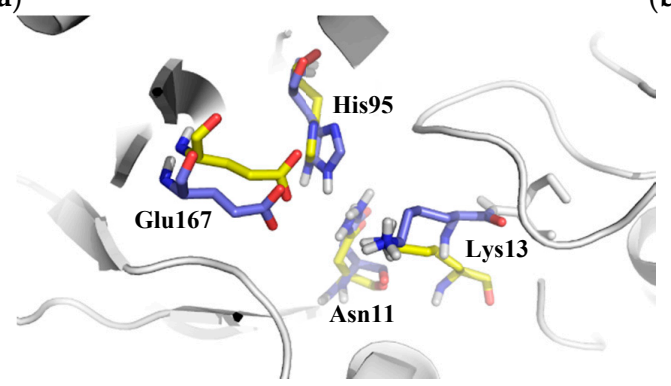

(c)

Figure 9. Movement of side chains from catalytic site residues in the Apo-TbTIM (blue sticks) and in complex with (a) compound 1; (b) compound 2; and (c) compound 3.

\subsection{Effects of Compounds on Human Triosphosphate Isomerase (HsTIM)}

When a therapeutic target is present in both the pathogen and in the host, a desirable characteristic is the selectivity of the inhibitors or inactivators. To this end, we studied the effects of these molecules in the HsTIM. Compounds were tested at the highest possible concentration, which depended on individual solubility. Results showed that molecules 1 and 2 inactivated 12\% and 23\% HsTIM, respectively, when they were tested at $100 \mu \mathrm{M}$ (Figure 10). At this concentration, TbTIM lost 77\% of its activity (Figure 2). Compound 3 was tested until $200 \mu \mathrm{M}$ (data not showed) and no effect on HsTIM activity was observed, whilst TbTIM lost $80 \%$ at the same concentration (Figure 2). Therefore, these compounds are selective for TbTIM with respect to the human counterpart.

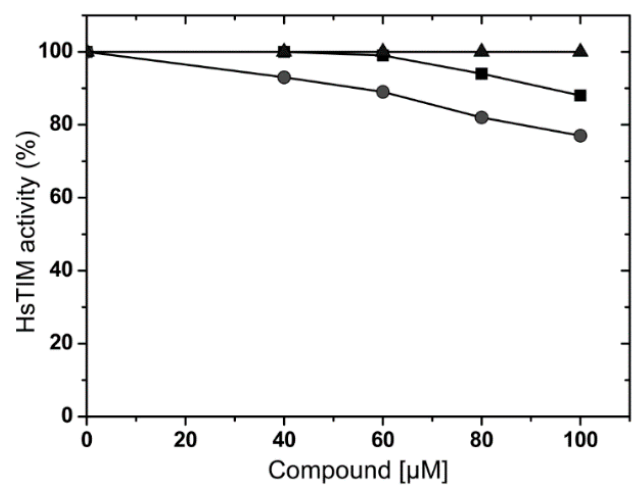

Figure 10. Inactivation of HsTIM by compounds 1 (squares), 2 (circles) and 3 (triangles). 


\subsection{In Silico Analysis of ADME-Tox Properties}

An important issue to address was the Administration, Distribution, Metabolism, and Excretion (ADME) properties and the possible toxicological effects of these compounds. Therefore, several in silico studies were made through different software available on the web (Table 2). With respect to ADME properties, data suggested that the three compounds bearing physicochemical characteristics to be considered as potential drug candidates. Toxicological analysis revealed that the predicted LD50, estimated in rodents, was closer to $1 \mathrm{~g} / \mathrm{Kg}$ in the three cases, suggesting no potential toxicological effects.

Table 2. Physicochemical and toxicological properties of TbTIM inactivators.

\begin{tabular}{cccccccc}
\hline Compound & cLogP $^{\mathbf{1}}$ & tPSA $^{\mathbf{1}}$ & HB-D $^{\mathbf{1}}$ & HB-A $^{\mathbf{1}}$ & VEBER Rules $^{\mathbf{1}}$ & EGAN Rules $^{\mathbf{1}}$ & Predicted LD50 $^{\mathbf{2}}$ (mg/kg) \\
\hline 1 & 4.1256 & 76.24 & 2 & 6 & Good & Good & 911 \\
2 & 5.3882 & 53.08 & 1 & 6 & Good & Good & 990 \\
3 & 1.9686 & 154.4 & 2 & 9 & Good & Good & 1000 \\
\hline 1 Obtained in FAFDrugs4 server; & ${ }^{2}$ Calculated in PROTOX-Prediction of Rodent Oral TOXicity server. cLogP, \\
logarithm of the partition coefficient between n-octanol and water; tPSA, topological polar surface area; HB-D, \\
hydrogen bond donors; HB-A, hydrogen bond acceptors.
\end{tabular}

\section{Materials and Methods}

\subsection{Synthesis and Molecular Characterization}

Compounds 1 and 2 were prepared from the appropriate o-phenylendiamine and carrying out our synthetic procedure previously reported for similar benzimidazole derivatives [31]. Compound 3 was synthesized beginning with 2-(methylthio)-1H-benzimidazole-5-carboxylic acid by a three reaction sequence: (1) preparation of tert-butyl 2-(2-(methylthio)-1H-benzimidazole-5-carbonyl) hydrazinecarboxylate, as intermediate, using tert-butyl carbazate, COMU ((1-cyano-2-ethoxy-2oxoethylidenaminooxy)dimethylamino-morpholino-carbenium hexafluorophosphate), NMM (4methylmorpholine) in $\mathrm{CH}_{2} \mathrm{Cl}_{2}$ at $\mathrm{rt}$; (2) hydrolysis of protecting group with TFA (trifluoroacetic acid); and (3) reaction with 5-nitrofuran-2-carbaldehyde in $\mathrm{CHCl}_{3}$ and acetic acid in catalytic amounts at $\mathrm{rt}$ for $12 \mathrm{~h}$.

Methyl(5-(naphthalen-1-yloxy)-1H-benzimidazol-2-yl)carbamate (1). Purified by $\mathrm{MeOH}$ washes. m.p. 227.6-229.8 ${ }^{\circ} \mathrm{C} .1 \mathrm{H} \mathrm{NMR}\left(\mathrm{DMSO}-d_{6} ; 400 \mathrm{MHz}\right) \delta: 3.73\left(\mathrm{~s}, 3 \mathrm{H},-\mathrm{OCH}_{3}\right), 6.82\left(\mathrm{~d}, J=7.6 \mathrm{~Hz}, 1 \mathrm{H}, \mathrm{H}-2^{\prime}\right)$, $6.90(\mathrm{dd}, J=8.6,2.4 \mathrm{~Hz}, 1 \mathrm{H}, \mathrm{H}-6), 7.08(\mathrm{~d}, J=2.3 \mathrm{~Hz}, 1 \mathrm{H}, \mathrm{H}-4), 7.41\left(\mathrm{t}, J=7.9 \mathrm{Jz}, 1 \mathrm{H}, \mathrm{H}-3^{\prime}\right), 7.43(\mathrm{~d}$, $J=8.6 \mathrm{~Hz}, 1 \mathrm{H}, \mathrm{H}-7), 7.52-7.61\left(\mathrm{~m}, 2 \mathrm{H}, \mathrm{H}-6^{\prime}, \mathrm{H}^{-} 7^{\prime}\right), 7.65\left(\mathrm{~d}, J=8.3 \mathrm{~Hz}, 1 \mathrm{H}, \mathrm{H}-5^{\prime}\right), 7.96(\mathrm{~d}, J=7.6 \mathrm{~Hz}$, $\left.1 \mathrm{H}, \mathrm{H}-4^{\prime}\right), 8.20\left(\mathrm{~d}, J=9.0 \mathrm{~Hz}, 1 \mathrm{H}, \mathrm{H}-8^{\prime}\right), 11.64(\mathrm{~s}, 2 \mathrm{H},-\mathrm{NH}) .{ }^{13} \mathrm{C}$ NMR (DMSO- $\left.d_{6} ; 100 \mathrm{MHz}\right) \delta: 52.5$, 104.6, 111.8, 113.2, 114.6, 121.6, 122.5, 125.8, 126.1, 126.2, 126.8, 127.9, 134.6, 148.0, 151.5, 154.0, 154.8. MS (EI $m / z)(\% \mathrm{ab}): 333\left(\mathrm{M}^{+}, 72 \%\right) ; 301(\mathrm{M}-32,100 \%) ; 272$ ([301 - 29], 21\%); 127 ([272 - 145], 16\%).

Methyl(5-((4-chloronaphthalen-1-yl)oxy)-1H-benzimidazol-2-yl)carbamate (2). Purified by MeOH washes. m.p. $248.7-253.5^{\circ} \mathrm{C} .1 \mathrm{H} \mathrm{NMR}\left(\mathrm{DMSO}-d_{6} ; 400 \mathrm{MHz}\right) \delta: 3.74\left(\mathrm{~s}, 3 \mathrm{H},-\mathrm{OCH}_{3}\right), 6.76(\mathrm{~d}, J=8.3 \mathrm{~Hz}, 1 \mathrm{H}$, H-2' $), 6.92(\mathrm{dd}, J=8.5,2.4 \mathrm{~Hz}, 1 \mathrm{H}, \mathrm{H}-6), 7.14(\mathrm{~d}, J=2.3 \mathrm{~Hz}, 1 \mathrm{H}, \mathrm{H}-4), 7.45$ (d, J = 8.5 Hz, 1H, H-7), 7.58 (d, $\left.J=8.3 \mathrm{~Hz}, 1 \mathrm{H}, \mathrm{H}-3^{\prime}\right), 7.69\left(\mathrm{ddd}^{\prime} J=8.1,6.9,1.1 \mathrm{~Hz}, 1 \mathrm{H}, \mathrm{H}-7^{\prime}\right), 7.77\left(\mathrm{ddd}, J=8.4,6.9,1.2 \mathrm{~Hz}, 1 \mathrm{H}, \mathrm{H}-6^{\prime}\right)$, $8.19\left(\mathrm{~d}, J=8.4 \mathrm{~Hz}, 1 \mathrm{H}, \mathrm{H}-5^{\prime}\right), 8.33\left(\mathrm{~d}, J=8.3 \mathrm{~Hz}, 1 \mathrm{H}, \mathrm{H}-8^{\prime}\right), 11.68(\mathrm{~s}, 2 \mathrm{H}) .{ }^{13} \mathrm{C}$ NMR $\left(\mathrm{DMSO}-d_{6} ; 100 \mathrm{MHz}\right)$ $\delta:$ 52.5, 105.0, 111.3, 113.4, 114.6, 122.3, 123.8, 123.9, 126.3, 126.6, 127.0, 128.4, 130.8, 148.0, 150.7, 153.7,

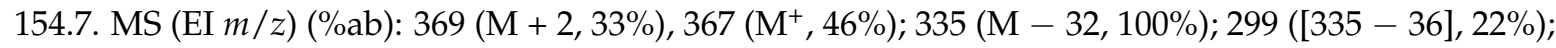
$272([299-27], 21 \%)$.

(E)-2-(Methylthio)-N'-((5-nitrofuran-2-yl)methylene)-1H-benzimidazole-5-carbohydrazide (3). Purified by chromatographic column using $\mathrm{CHCl}_{3} / \mathrm{MeOH}$ (95:5) as eluent. m.p. $202.1{ }^{\circ} \mathrm{C}$ with decomposition. 1H NMR (DMSO-d $\left.d_{6} 400 \mathrm{MHz}\right) \delta: 2.74\left(\mathrm{~s}, 3 \mathrm{H}, \mathrm{S}-\mathrm{CH}_{3}\right), 6.69$ (bs, 1H, N-H), $7.24(\mathrm{~d}, J=4 \mathrm{~Hz}, 1 \mathrm{H}$, H-3') 7.56 (d, J = 12 H, 1H, H-7), 7.76 (m, 2H, H-6, H-4'), 8.06 (s, 1H, H-4), 8.41 (s, 1H, N=C-H), 
$12.23(\mathrm{~s}, 1 \mathrm{H}, \mathrm{CON}-\mathrm{H}) .{ }^{13} \mathrm{C}$ NMR (DMSO- $\left.d_{6} ; 100 \mathrm{MHz}\right) \delta: 14.3$ (double signal), 113.7 (double signal), 115.1 (double signal), 122.5, 126.7, 135.4, 138.9, 141.7, 152.3, 152.4, 154.9, 158.6, 159.1, 164.1 .

\subsection{Expression and Purification of TIMs}

The proteins TbTIM and HsTIM were expressed in Escherichia coli and purified as described in the literature [54], obtaining a 95\% of purity measured by densitometric analysis. After purification, enzymes were dissolved in $100 \mathrm{mM}$ triethanolamine, $10 \mathrm{mM}$ EDTA, and $1 \mathrm{mM}$ DTT (pH 8). Then, they were precipitated with $\left(\mathrm{NH}_{4}\right)_{2} \mathrm{SO}_{4}\left(80 \%\right.$ saturation) for storage at $4{ }^{\circ} \mathrm{C}$. Before use, exhaustive dialysis against $100 \mathrm{mM}$ triethanolamine, $10 \mathrm{mM}$ EDTA (pH 7.4) was performed. Protein concentration was determined by absorbance at $280 \mathrm{~nm}$ using a molar extinction coefficientof 34,950 and $33,460 \mathrm{M}^{-1} \cdot \mathrm{cm}^{-1}$ for TbTIM and HsTIM, respectively.

\subsection{Enzymatic Activity Assays}

Enzymatic activity was determined in an enzyme-coupled reaction using $\alpha$-glycerol phosphate dehydrogenase, in the direction of glyceraldehyde 3-phosphate (GAP) to dihydroxyacetone phosphate, as reported elsewhere $[11,17,19]$. The decrease in absorbance at $340 \mathrm{~nm}$ was followed in a multicell Agilent (Santa Clara, CA, USA) spectrophotometer at $25^{\circ} \mathrm{C}$. The reaction mixture contained $100 \mathrm{mM}$ triethanolamine, $10 \mathrm{mM}$ EDTA, $0.2 \mathrm{mM} \mathrm{NADH}, 1 \mathrm{mM} \mathrm{GAP}$, and $90 \mathrm{ng} / \mathrm{mL}$ of $\alpha$-glycerol phosphate dehydrogenase ( $\alpha$-GPDH) (pH 7.4). The reaction was initiated by addition of $5 \mathrm{ng} / \mathrm{mL}$ either TbTIM or HsTIM.

\subsection{Inactivation Assays}

The enzyme was incubated at $5 \mu \mathrm{g} / \mathrm{mL}$ in $100 \mathrm{mM}$ triethanolamine, $10 \mathrm{mM}$ EDTA ( $\mathrm{pH}$ 7.4), $10 \%(v / v)$ DMSO, and the compound at the indicated concentration at $36{ }^{\circ} \mathrm{C}$ for $2 \mathrm{~h}$. After this, aliquots of the mixture were withdrawn to perform the activity assay above mentioned. The initial screening was perfomed testing our in-house chemical library (200 compounds), at a concentration of $200 \mu \mathrm{M}$. The $\mathrm{I}_{50}$ value (concentration of the compound needed to reduce the enzymatic activity to $50 \%$ ) was determined through curves at different compound concentrations and adjusting the data to the equation reported elsewhere [17].

Enzyme inactivation velocity was determined by a pseudo first order rate constant $\left(\mathrm{k}_{\mathrm{obs}}\right)$, measuring activity at different times and a fixed compound concentration, adjusting the data to Equation (1)

$$
A=A_{0} e^{-k t},
$$

where $A$ is the activity at the indicated compound concentration, $A_{0}$ is the activity in the absence of compound, $k$ is the pseudo-first order constant, and $t$ is the time.

\subsection{Molecular Docking}

Ligand parameters, such as torsions, atom types and atomic partial charges of Gasteiger-Marsilli [55], were generated using AutoDock Tools (ADT) 4.2 (La Jolla, CA, USA) [56]. The protein structure was obtained from the Protein Data Bank with PDB-ID 2J27 [57]. Protein was prepared adding hydrogen and atomic partial charges of Gasteiger using ADT 4.2. Docking simulations were performed using AutoDock 4.0 (La Jolla, CA, USA) [58] and the Lamarckian genetic algorithm with a grid size of $X=82, Y=40$ and $Z=42$ points, centered at the dimer interface. One hundred runs of the genetic algorithm were performed for each ligand-receptor pair using the default parameters. The output ligand configurations were clustered and the best binding energy scores were selected for the molecular dynamics simulations. 


\subsection{Molecular Dynamics}

Ligands parameterizations were performed in a PRODRG server [59] with a GROMOS87 force field (Biomos b.v., Laboratory of Physical Chemistry, Zürich, Switzerland) [60]. All simulations were carried out using the GROMOS9643a1 force field [61]. At the begining, an energy minimization using 500 cycles of the steepest-descent algorithm was executed. The first velocities were assigned according to the Maxwell distribution to $10 \mathrm{~K}$ temperature and it was gradually increased to $300 \mathrm{~K}$. After that, we carried out a canonical (NVT) [62] and isothermal-isobaric (NPT) [63] simulations (with isotropic position scaling) at $300 \mathrm{~K}$ and $1 \mathrm{~atm}$ pressure, using a truncated cubic periodic box with dimensions of $100 \AA$, filled with Simple point charge water model [64] and neutralized with $\mathrm{Na}^{+}$and $\mathrm{Cl}^{-}$ions. Finally, we performed a complete molecular dynamics simulation of $100 \mathrm{~ns}$ at $300 \mathrm{~K}$ without restrictions using the software GROMACS 5.1 (Groningen Biomolecular Sciences and Biotechnology Institute, Groningen, The Netherlands) [65], obtaining 10,000 conformations that were saved every 5000 steps.

\subsection{Binding Energy}

The calculation of the binding free energy was based on the linear interaction energy (LIE) method by the Equation (2):

$$
\Delta \mathrm{G}_{\text {bind }}=\alpha\left[\left(\mathrm{V}_{\mathrm{LJ}}\right)_{\text {bound }}-\left(\mathrm{V}_{\mathrm{LJ}}\right)_{\text {free }}\right]+\beta\left[\left(\mathrm{V}_{\mathrm{CL}}\right)_{\text {bound }}-\left(\mathrm{V}_{\mathrm{CL}}\right)_{\text {free }}\right]+\gamma
$$

where $\left(\mathrm{V}_{\mathrm{LJ}}\right)_{\text {bound }}$ is the average Lennard-Jones energy for ligand-protein interaction; $\left(\mathrm{V}_{\mathrm{LJ}}\right)_{\text {free }}$ is the average Lennard-Jones energy for ligand-water interaction; $\left(V_{C L}\right)_{b o u n d}$ is the average electrostatic energy for ligand-protein interaction; $\left(\mathrm{V}_{\mathrm{CL}}\right)_{\text {free }}$ is the average electrostatic energy for ligand-water interaction; $\alpha, \beta$, and $\gamma$ are the LIE coefficients. For small drug-like ligands, $\alpha=0.18, \beta=0.50$ and $\gamma=0.00[66-68]$.

\subsection{Toxicological and Physicochemical Properties}

The Faf-Drugs4 server [69] was used for calculating relevant drug-like properties and the web server PROTOX [70] was used to predict LD50.

\section{Conclusions}

Three new benzimidazole derivatives were found with the capacity to inactivate selectively the TbTIM with respect to the HsTIM, and with the characteristics to be considered as potential drug candidates. Therefore, these molecules will serve as a guide for the design of more potent inactivators that could be used to obtain new drugs against HAT.

Supplementary Materials: The supplementary materials are available online. Figure S1: Complete view of the binding mode of compounds (a) 1; (b) 2; and (c) 3, at the dimer interface of TbTIM predicted by docking. For compounds $\mathbf{1}$ and 2, the two molecules are displayed. Molecular surface is drawn as a purple grid, Figure S2: RMSF comparison between Apo-TbTIM and the complexes with compounds 1, 2 and 3. (a) Loop 6 residues; (b) Loop 8 residues.

Acknowledgments: A.T.-V. and C.A.-D. acknowledge Consejo Nacional de Ciencia y Tecnología (CONACyT) for grants No. 257848 and No. 258694, respectively. R.C. and A.H.-C. acknowledge CONACyT for financial support of project No. 251726 and DGAPA-PAPIIT, UNAM for project No. IN221416. CONACyT is also acknowledged for the fellowship granted to A.V.-R. (No. 521240), L.C.-G. (No. 738111/596643) and P.J.T.-S. (No. 409406/No. 258048). We thank Rosa Isela del Villar Morales and Nayeli López Baliaux for the determination of NMR spectra.

Author Contributions: Performed the experiments: A.V.-R. and A.C.-V. Synthesis of active compounds: L.C.-G., I.V.-M., and P.J.T.-S. Conceived and designed benzimidazole derivatives library: R.C., A.H.-C. and F.H.-L. Conceived, designed the experiments and contributed reagents/materials/analysis tools: R.C., A.H.-C., C.A.-D., J.O.-H. and A.T.-V. Analyzed the data and wrote the paper: A.V.-R., C.A.-D., E.S.-C., M.V.-S. and A.T.-V.

Conflicts of Interest: The authors declare no conflict of interest. 


\section{References}

1. W.H.O. Trypanosomiasis, Human African (Sleeping Sickness), Epidemiological Situation. Available online: http:/ / www.who.int/trypanosomiasis_african/country/en/ (accessed on 17 September 2017).

2. Fairlamb, A.H. Chemotherapy of human African trypanosomiasis: Current and future prospects. Trends Parasitol. 2003, 19, 488-494. [CrossRef] [PubMed]

3. Likeufack, A.L.; Brun, R.; Fomena, A.; Truc, P. Comparison of the in vitro drug sensitivity of Trypanosoma brucei gambiense strains from West and Central Africa isolated in the periods 1960-1995 and 1999-2004. Acta Trop. 2006, 100, 11-16. [CrossRef] [PubMed]

4. Maina, N.; Maina, K.J.; Mäser, P.; Brun, R. Genotypic and phenotypic characterization of Trypanosoma brucei gambiense isolates from Ibba, South Sudan, an area of high melarsoprol treatment failure rate. Acta Trop. 2007, 104, 84-90. [CrossRef] [PubMed]

5. Delespaux, V.; de Koning, H.P. Drugs and drug resistance in African trypanosomiasis. Drug Resist. Updat. 2007, 10, 30-50. [CrossRef] [PubMed]

6. Stewart, M.L.; Burchmore, R.J.; Clucas, C.; Hertz-Fowler, C.; Brooks, K.; Tait, A.; MacLeod, A.; Turner, C.M.R.; De Koning, H.P.; Wong, P.E. Multiple genetic mechanisms lead to loss of functional TbAT1 expression in drug-resistant trypanosomes. Eukaryot. Cell 2010, 9, 336-343. [CrossRef] [PubMed]

7. Graf, F.E.; Ludin, P.; Wenzler, T.; Kaiser, M.; Brun, R.; Pyana, P.P.; Büscher, P.; De Koning, H.P.; Horn, D.; Mäser, P. Aquaporin 2 mutations in Trypanosoma brucei gambiense field isolates correlate with decreased susceptibility to pentamidine and melarsoprol. PLoS Negl. Trop. Dis. 2013, 7, e2475. [CrossRef] [PubMed]

8. World Health Organization (WHO). Control and Surveillance of Human African Trypanosomiasis: Report of a WHO Expert Committee. 1998. Available online: http:/ /apps.who.int/iris/bitstream/10665/42087/1/ WHO_TRS_881.pdf (accessed on 17 September 2017).

9. Albert, M.-A.; Haanstra, J.R.; Hannaert, V.; Van Roy, J.; Opperdoes, F.R.; Bakker, B.M.; Michels, P.A. Experimental and in silico analyses of glycolytic flux control in bloodstream form Trypanosoma brucei. J. Biol. Chem. 2005, 280, 28306-28315. [CrossRef] [PubMed]

10. Helfert, S.; Estévez, A.M.; Bakker, B.; Michels, P.; Clayton, C. Roles of triosephosphate isomerase and aerobic metabolism in Trypanosoma brucei. Biochem. J. 2001, 357, 117-125. [CrossRef] [PubMed]

11. Olivares-Illana, V.; Pérez-Montfort, R.; López-Calahorra, F.; Costas, M.; Rodríguez-Romero, A.; Tuena de Gómez-Puyou, M.; Gómez Puyou, A. Structural differences in triosephosphate isomerase from different species and discovery of a multitrypanosomatid inhibitor. Biochemistry 2006, 45, 2556-2560. [CrossRef] [PubMed]

12. Galland, N.; de Walque, S.; Voncken, F.G.; Verlinde, C.L.; Michels, P.A. An internal sequence targets Trypanosoma brucei triosephosphate isomerase to glycosomes. Mol. Biochem. Parasitol. 2010, 171, 45-49. [CrossRef] [PubMed]

13. Clayton, C.E.; Michels, P. Metabolic compartmentation in African trypanosomes. Parasitol. Today 1996, 12, 465-471. [CrossRef]

14. Schnackerz, K.D.; Gracy, R.W. Probing the catalytic sites of triosephosphate isomerase by 31P-NMR with reversibly and irreversibly binding substrate analogues. FEBS J. 1991, 199, 231-238. [CrossRef]

15. Kursula, I.; Partanen, S.; Lambeir, A.M.; Antonov, D.M.; Augustyns, K.; Wierenga, R.K. Structural determinants for ligand binding and catalysis of triosephosphate isomerase. FEBS J. 2001, 268, 5189-5196. [CrossRef]

16. Wierenga, R.; Noble, M.; Vriend, G.; Nauche, S.; Hol, W. Refined $1.83 \AA$ structure of trypanosomal triosephosphate isomerase crystallized in the presence of $2.4 \mathrm{M}$-ammonium sulphate: A comparison with the structure of the trypanosomal triosephosphate isomerase-glycerol-3-phosphate complex. J. Mol. Biol. 1991, 220, 995-1015. [CrossRef]

17. Téllez-Valencia, A.; Ávila-Ríos, S.; Pérez-Montfort, R.; Rodríguez-Romero, A.; de Gómez-Puyou, M.T.; López-Calahorra, F.; Gómez-Puyou, A. Highly specific inactivation of triosephosphate isomerase from Trypanosoma cruzi. Biochem. Biophys. Res. Commun. 2002, 295, 958-963. [CrossRef]

18. Zomosa-Signoret, V.; Hernández-Alcántara, G.; Reyes-Vivas, H.; Martínez-Martínez, E.; Garza-Ramos, G.; Pérez-Montfort, R.; Tuena de Gómez-Puyou, M.; Gómez-Puyou, A. Control of the reactivation kinetics of homodimeric triosephosphate isomerase from unfolded monomers. Biochemistry 2003, 42, 3311-3318. [CrossRef] [PubMed] 
19. Gayosso-De-Lucio, J.; Torres-Valencia, M.; Rojo-Domínguez, A.; Nájera-Peña, H.; Aguirre-López, B.; Salas-Pacheco, J.; Avitia-Domínguez, C.; Téllez-Valencia, A. Selective inactivation of triosephosphate isomerase from Trypanosoma cruzi by brevifolin carboxylate derivatives isolated from Geranium bellum Rose. Bioorg. Med. Chem. Lett. 2009, 19, 5936-5939. [CrossRef] [PubMed]

20. Kuntz, D.A.; Osowski, R.; Schudok, M.; Wierenga, R.K.; Müller, K.; Kessler, H.; Opperdoes, F.R. Inhibition of triosephosphate isomerase from Trypanosoma brucei with cyclic hexapeptides. FEBS J. 1992, 207, 441-447. [CrossRef]

21. Alvarez, G.; Martínez, J.; Aguirre-Lopez, B.; Cabrera, N.; Pérez-Díaz, L.; de Gómez-Puyou, M.T.; Gómez-Puyou, A.; Pérez-Montfort, R.; Garat, B.; Merlino, A. New chemotypes as Trypanosoma cruzi triosephosphate isomerase inhibitors: A deeper insight into the mechanism of inhibition. J. Enzym. Inhib. Med. Chem. 2014, 29, 198-204. [CrossRef] [PubMed]

22. Bansal, Y.; Silakari, O. The therapeutic journey of benzimidazoles: A review. Bioorg. Med. Chem. 2012, 20, 6208-6236. [CrossRef] [PubMed]

23. Hong, S.-Y.; Chung, K.-H.; You, H.-J.; Choi, I.H.; Chae, M.J.; Han, J.-Y.; Jung, O.-J.; Kang, S.-J.; Ryu, C.-K. Synthesis and biological evaluation of benzimidazole-4,7-diones that inhibit vascular smooth muscle cell proliferation. Bioorg. Med. Chem. Lett. 2004, 14, 3563-3566. [CrossRef] [PubMed]

24. Kuş, C.; Ayhan-Kılcıgil, G.; Özbey, S.; Kaynak, F.B.; Kaya, M.; Çoban, T.; Can-Eke, B. Synthesis and antioxidant properties of novel $\mathrm{N}$-methyl-1,3,4-thiadiazol-2-amine and 4-methyl-2H-1,2,4triazole-3(4H)-thione derivatives of benzimidazole class. Bioorg. Med. Chem. 2008, 16, 4294-4303. [CrossRef] [PubMed]

25. Sharma, D.; Narasimhan, B.; Kumar, P.; Judge, V.; Narang, R.; De Clercq, E.; Balzarini, J. Synthesis, antimicrobial and antiviral activity of substituted benzimidazoles. J. Enzym. Inhib. Med. Chem. 2009, 24, 1161-1168. [CrossRef] [PubMed]

26. Hosamani, K.M.; Seetharamareddy, H.R.; Keri, R.S.; Hanamanthagouda, M.S.; Moloney, M.G. Microwave assisted, one-pot synthesis of 5-nitro-2-aryl substituted-1H-benzimidazole libraries: Screening in vitro for antimicrobial activity. J. Enzym. Inhib. Med. Chem. 2009, 24, 1095-1100. [CrossRef] [PubMed]

27. Abonia, R.; Cortés, E.; Insuasty, B.; Quiroga, J.; Nogueras, M.; Cobo, J. Synthesis of novel 1,2,5-trisubstituted benzimidazoles as potential antitumor agents. Eur. J. Med. Chem. 2011, 46, 4062-4070. [CrossRef] [PubMed]

28. Miller, J.F.; Turner, E.M.; Gudmundsson, K.S.; Jenkinson, S.; Spaltenstein, A.; Thomson, M.; Wheelan, P. Novel $N$-substituted benzimidazole CXCR4 antagonists as potential anti-HIV agents. Bioorg. Med. Chem. 2010, 20, 2125-2128. [CrossRef] [PubMed]

29. Flores-Carrillo, P.; Velázquez-López, J.M.; Aguayo-Ortiz, R.; Hernández-Campos, A.; Trejo-Soto, P.J.; Yépez-Mulia, L.; Castillo, R. Synthesis, antiprotozoal activity, and chemoinformatic analysis of 2-(methylthio)-1H-benzimidazole-5-carboxamide derivatives: Identification of new selective giardicidal and trichomonicidal compounds. Eur. J. Med. Chem. 2017, 137, 211-220. [CrossRef] [PubMed]

30. Kwak, H.J.; Pyun, Y.M.; Kim, J.Y.; Pagire, H.S.; Kim, K.Y.; Kim, K.R.; Dal Rhee, S.; Jung, W.H.; Song, J.S.; Bae, M.A. Synthesis and biological evaluation of aminobenzimidazole derivatives with a phenylcyclohexyl acetic acid group as anti-obesity and anti-diabetic agents. Bioorg. Med. Chem. 2013, 23, 4713-4718. [CrossRef] [PubMed]

31. Soria-Arteche, O.; Hernández-Campos, A.; Yépez-Mulia, L.; Trejo-Soto, P.J.; Hernández-Luis, F.; Gres-Molina, J.; Maldonado, L.A.; Castillo, R. Synthesis and antiprotozoal activity of nitazoxanide- $N$ methylbenzimidazole hybrids. Bioorg. Med. Chem. 2013, 23, 6838-6841. [CrossRef] [PubMed]

32. Flores-Ramos, M.; Ibarra-Velarde, F.; Hernández-Campos, A.; Vera-Montenegro, Y.; Jung-Cook, H.; Cantó-Alarcón, G.J.; del Rivero, L.M.; Castillo, R. A highly water soluble benzimidazole derivative useful for the treatment of fasciolosis. Bioorg. Med. Chem. 2014, 24, 5814-5817. [CrossRef] [PubMed]

33. Aguayo-Ortiz, R.; Pérez-Villanueva, J.; Hernández-Campos, A.; Castillo, R.; Meurice, N.; Medina-Franco, J.L. Chemoinformatic characterization of activity and selectivity switches of antiprotozoal compounds. Future Med. Chem. 2014, 6, 281-294. [CrossRef] [PubMed]

34. Matadamas-Martínez, F.; Castillo, R.; Hernández-Campos, A.; Méndez-Cuesta, C.; de Souza, W.; Gadelha, A.P.; Nogueda-Torres, B.; Hernández, J.M.; Yépez-Mulia, L. Proteomic and ultrastructural analysis of the effect of a new nitazoxanide- $\mathrm{N}$-methyl-1H-benzimidazole hybrid against Giardia intestinalis. Res. Vet. Sci. 2016, 105, 171-179. [CrossRef] [PubMed] 
35. Flores-Ramos, M.; Ibarra-Velarde, F.; Jung-Cook, H.; Hernández-Campos, A.; Vera-Montenegro, Y.; Castillo, R. Novel triclabendazole prodrug: A highly water soluble alternative for the treatment of fasciolosis. Bioorg. Med. Chem. 2017, 27, 616-619. [CrossRef] [PubMed]

36. Romo-Mancillas, A.; Téllez-Valencia, A.; Yépez-Mulia, L.; Hernández-Luis, F.; Hernández-Campos, A.; Castillo, R. The design and inhibitory profile of new benzimidazole derivatives against triosephosphate isomerase from Trypanosoma cruzi: A problem of residue motility. J. Mol. Graph. Model. 2011, 30, 90-99. [CrossRef] [PubMed]

37. Díaz-Chiguer, D.L.; Hernández-Luis, F.; Nogueda-Torres, B.; Castillo, R.; Reynoso-Ducoing, O.; Hernández-Campos, A.; Ambrosio, J.R. JVG9, a benzimidazole derivative, alters the surface and cytoskeleton of Trypanosoma cruzi bloodstream trypomastigotes. Mem. Inst. Oswaldo Cruz 2014, 109, 757-760. [CrossRef] [PubMed]

38. Velázquez-López, J.M.; Hernández-Campos, A.; Yépez-Mulia, L.; Téllez-Valencia, A.; Flores-Carrillo, P.; Nieto-Meneses, R.; Castillo, R. Synthesis and trypanocidal activity of novel benzimidazole derivatives. Eur. J. Med. Chem. Lett. 2016, 26, 4377-4381. [CrossRef] [PubMed]

39. Pettigrew, D.W. Inactivation of Escherichia coli glycerol kinase by 5,5'-dithiobis (2-nitrobenzoic acid) and $N$-ethylmaleimide: Evidence for nucleotide regulatory binding sites. Biochemistry 1986, 25, 4711-4718. [CrossRef] [PubMed]

40. Alvarez, G.; Aguirre-López, B.; Cabrera, N.; Marins, E.B.; Tinoco, L.; Batthyány, C.I.; de Gómez-Puyou, M.T.; Puyou, A.G.; Pérez-Montfort, R.; Cerecetto, H. 1,2,4-thiadiazol-5(4H)-ones: A new class of selective inhibitors of Trypanosoma cruzi triosephosphate isomerase. Study of the mechanism of inhibition. J. Enzym. Inhib. Med. Chem. 2013, 28, 981-989. [CrossRef] [PubMed]

41. Minini, L.; Álvarez, G.; González, M.; Cerecetto, H.; Merlino, A. Molecular docking and molecular dynamics simulation studies of Trypanosoma cruzi triosephosphate isomerase inhibitors. Insights into the inhibition mechanism and selectivity. J. Mol. Graph. Model. 2015, 58, 40-49. [CrossRef] [PubMed]

42. Kurkcuoglu, Z.; Findik, D.; Akten, E.D.; Doruker, P. How an inhibitor bound to subunit interface alters triosephosphate isomerase dynamics. Biophys. J. 2015, 109, 1169-1178. [CrossRef] [PubMed]

43. Téllez-Valencia, A.; Olivares-Illana, V.; Hernández-Santoyo, A.; Pérez-Montfort, R.; Costas, M.; Rodríguez-Romero, A.; López-Calahorra, F.; de Gómez-Puyou, M.T.; Gómez-Puyou, A. Inactivation of triosephosphate isomerase from Trypanosoma cruzi by an agent that perturbs its dimer interface. J. Mol. Biol. 2004, 341, 1355-1365. [CrossRef] [PubMed]

44. Espinoza-Fonseca, L.M.; Trujillo-Ferrara, J.G. Exploring the possible binding sites at the interface of triosephosphate isomerase dimer as a potential target for anti-tripanosomal drug design. Bioorg. Med. Chem. 2004, 14, 3151-3154. [CrossRef] [PubMed]

45. Espinoza-Fonseca, L.M.; Trujillo-Ferrara, J.G. Structural considerations for the rational design of selective anti-trypanosomal agents: The role of the aromatic clusters at the interface of triosephosphate isomerase dimer. Biochem. Biophys. Res. Commun. 2005, 328, 922-928. [CrossRef] [PubMed]

46. Zabori, S.; Rudolph, R.; Jaenicke, R. Folding and association of triose phosphate isomerase from rabbit muscle. Z. Naturforsch. C 1980, 35, 999-1004. [PubMed]

47. Pompliano, D.L.; Peyman, A.; Knowles, J.R. Stabilization of a reaction intermediate as a catalytic device: Definition of the functional role of the flexible loop in triosephosphate isomerase. Biochemistry 1990, 29, 3186-3194. [CrossRef] [PubMed]

48. Borchert, T.V.; Kishan, K.R.; Zeelen, J.P.; Schliebs, W.; Thanki, N.; Abagyan, R.; Jaenicke, R.; Wierenga, R.K. Three new crystal structures of point mutation variants of mono TIM: Conformational flexibility of loop-1, loop-4 and loop-8. Structure 1995, 3, 669-679. [CrossRef]

49. Thakur, S.S.; Deepalakshmi, P.; Gayathri, P.; Banerjee, M.; Murthy, M.; Balaram, P. Detection of the protein dimers, multiple monomeric states and hydrated forms of Plasmodium falciparum triosephosphate isomerase in the gas phase. Protein Eng. Des. Sel. 2009, 22, 289-304. [CrossRef] [PubMed]

50. Alahuhta, M.; Salin, M.; Casteleijn, M.G.; Kemmer, C.; El-Sayed, I.; Augustyns, K.; Neubauer, P.; Wierenga, R.K. Structure-based protein engineering efforts with a monomeric TIM variant: The importance of a single point mutation for generating an active site with suitable binding properties. Protein Eng. Des. Sel. 2008, 21, 257-266. [CrossRef] [PubMed]

51. Wang, Y.; Berlow, R.B.; Loria, J.P. The role of loop-loop interactions in coordinating motions and enzymatic function in triosephosphate isomerase. Biochemistry 2009, 48, 4548. [CrossRef] [PubMed] 
52. Wierenga, R.; Kapetaniou, E.; Venkatesan, R. Triosephosphate isomerase: A highly evolved biocatalyst. Cell Mol. Life Sci. 2010, 67, 3961-3982. [CrossRef] [PubMed]

53. Zhai, X.; Go, M.K.; O’Donoghue, A.C.; Amyes, T.L.; Pegan, S.D.; Wang, Y.; Loria, J.P.; Mesecar, A.D.; Richard, J.P. Enzyme architecture: The effect of replacement and deletion mutations of loop 6 on catalysis by triosephosphate isomerase. Biochemistry 2014, 53, 3486. [CrossRef] [PubMed]

54. Borchert, T.V.; Pratt, K.; Zeelen, J.P.; Callens, M.; Noble, M.E.; Opperdoes, F.R.; Michels, P.A.; Wierenga, R.K. Overexpression of trypanosomal triosephosphate isomerase in Escherichia coli and characterisation of a dimer-interface mutant. FEBS J. 1993, 211, 703-710. [CrossRef]

55. Gasteiger, J.; Marsili, M. Iterative partial equalization of orbital electronegativity-A rapid access to atomic charges. Tetrahedron 1980, 36, 3219-3228. [CrossRef]

56. Morris, G.M.; Huey, R.; Lindstrom, W.; Sanner, M.F.; Belew, R.K.; Goodsell, D.S.; Olson, A.J. AutoDock4 and AutoDockTools4: Automated docking with selective receptor flexibility. J. Comput. Chem. 2009, 30, 2785-2791. [CrossRef] [PubMed]

57. Casteleijn, M.G.; Alahuhta, M.; Groebel, K.; El-Sayed, I.; Augustyns, K.; Lambeir, A.-M.; Neubauer, P.; Wierenga, R.K. Functional role of the conserved active site proline of triosephosphate isomerase. Biochemistry 2006, 45, 15483-15494. [CrossRef] [PubMed]

58. Morris, G.M.; Goodsell, D.S.; Halliday, R.S.; Huey, R.; Hart, W.E.; Belew, R.K.; Olson, A.J. Automated docking using a Lamarckian genetic algorithm and an empirical binding free energy function. J. Comput. Chem. 1998, 19, 1639-1662. [CrossRef]

59. Schuèttelkopf, A.W.; Van Aalten, D.M. PRODRG: A tool for high-throughput crystallography of protein-ligand complexes. Acta Crystallogr. D Biol. Crystallogr. 2004, 60, 1355-1363. [CrossRef] [PubMed]

60. Scott, W.; van Gunsteren, W. The GROMOS software package for biomolecular simulations. METECC 1995, 95, 397-434.

61. Kony, D.B.; Hünenberger, P.H.; Van Gunsteren, W.F. Molecular dynamics simulations of the native and partially folded states of ubiquitin: Influence of methanol cosolvent, $\mathrm{pH}$, and temperature on the protein structure and dynamics. Protein Sci. 2007, 16, 1101-1118. [CrossRef] [PubMed]

62. Berendsen, H.J.C.; Postma, J.P.M.; van Gunsteren, W.F.; DiNola, A.; Haak, J.R. Molecular dynamics with coupling to an external bath. J. Chem. Phys. 1984, 81, 3684-3690. [CrossRef]

63. Pastor, R.W.; Brooks, B.R.; Szabo, A. An analysis of the accuracy of Langevin and molecular dynamics algorithms. Mol. Phys. 1988, 65, 1409-1419. [CrossRef]

64. Jorgensen, W.L.; Chandrasekhar, J.; Madura, J.D.; Impey, R.W.; Klein, M.L. Comparison of simple potential functions for simulating liquid water. J. Chem. Phys. 1983, 79, 926-935. [CrossRef]

65. Van Der Spoel, D.; Lindahl, E.; Hess, B.; Groenhof, G.; Mark, A.E.; Berendsen, H.J. GROMACS: Fast, flexible, and free. J. Comput. Chem. 2005, 26, 1701-1718. [CrossRef] [PubMed]

66. Åqvist, J.; Medina, C.; Samuelsson, J.-E. A new method for predicting binding affinity in computer-aided drug design. Protein Eng. 1994, 7, 385-391. [CrossRef] [PubMed]

67. Punkvang, A.; Saparpakorn, P.; Hannongbua, S.; Wolschann, P.; Beyer, A.; Pungpo, P. Investigating the structural basis of arylamides to improve potency against $\mathrm{M}$. tuberculosis strain through molecular dynamics simulations. Eur. J. Med. Chem. 2010, 45, 5585-5593. [CrossRef] [PubMed]

68. Aguayo-Ortiz, R.; Méndez-Lucio, O.; Medina-Franco, J.L.; Castillo, R.; Yépez-Mulia, L.; Hernández-Luis, F.; Hernández-Campos, A. Towards the identification of the binding site of benzimidazoles to $\beta$-tubulin of Trichinella spiralis: Insights from computational and experimental data. J. Mol. Graph. Model. 2013, 41, 12-19. [CrossRef] [PubMed]

69. Faf-Drugs4 Server. Available online: http:/ / fafdrugs3.mti.univ-paris-diderot.fr/ (accessed on 20 July 2017).

70. PROTOX_Prediction of Rodent Oral TOXicity. Available online: http://tox.charite.de/tox/ (accessed on 20 July 2017).

Sample Availability: Samples of the compounds are not available from the authors.

(C) 2017 by the authors. Licensee MDPI, Basel, Switzerland. This article is an open access article distributed under the terms and conditions of the Creative Commons Attribution (CC BY) license (http://creativecommons.org/licenses/by/4.0/). 